\title{
A representação discursiva do ator social Michael Jackson e de sua morte em gêneros da esfera jornalística ${ }^{1}$
}

\author{
Discursive Representation of Social Actor \\ Michael Jackson and his Death in Journalistic Genres
}

\begin{abstract}
Maria Aparecida Resende Ottoni Universidade Federal de Uberlândia
\end{abstract}

\section{Resumo}

Neste artigo, investigamos como se dá a representação discursiva de um mesmo fato e do principal ator social nele envolvido, em diferentes gêneros distintos, a saber: reportagem; notícia; editorial; artigo de opinião; e carta do leitor. Nosso intuito é perquirir se há diferenças nas escolhas para representação de um mesmo fato e no modo como o ator social principal é representado nesses gêneros, bem como quais as razões e efeitos dessas diferenças. Nesse sentido, selecionamos textos que tratam da morte de Michael Jackson, os quais são analisados com base nos pressupostos da Análise de Discurso Crítica e na proposta de van Leeuwen (1997) para o estudo da representação de atores sociais. A análise revelou que, em todos os gêneros, a representação de modo ativo, pessoal e por classificação específica é dominante e que, nos gêneros que representam os núcleos jornalista e empresa predomina a nomeação e, nos que retratam os núcleos colaborador e leitor, a classificação. Prevalece, ainda, a classificação por valoração, o que colabora, sobremaneira, para a produção de uma mescla na representação do ator social Michael Jackson. Essa mescla também é marcada por meio da intertextualidade manifesta. 


\section{Palavras-chave}

Significado representacional, discurso, gêneros da esfera jornalística, mídia.

\section{Abstract}

In this paper, we investigate how the discursive representation of a same social fact, and the main social actors involved in it, is presented in different text genres, for example, news report, editorial, opinion article, and reader's letter. Our aim is to investigate whether there are differences in the choices made to represent the same fact and how the main social actor is represented in these genres, as well as the reasons underlying these differences and their consequences. To do this, we selected texts that address the death of Michael Jackson, which are analyzed based on the assumptions of Critical Discourse Analysis and on van Leeuwen's (1997) proposal to the study of the social actor representation. The analysis revealed that, in all genres, the representation of active and personal mode, as well as the specific classification, is dominant. Also, in genres that represent journalist and company cores, nomination is prevalent, whereas in genres that represent collaborator and reader cores, classification is dominant. Moreover, classification by valuation is also prevalent, which greatly corroborates the production of a mixture in the representation of social actor Michael Jackson. This mixture is also marked by means of overt intertextuality.

\section{Keywords}

Representation of meaning, discourse, genres of the journalistic domain, media studies. 


\section{Considerações iniciais}

que se observou em 25 de junho de 2009 - data da morte de Michael
Joseph Jackson - e em longo período depois dessa data foi uma
produção e reprodução de textos sobre a sua morte e a sua vida, nas redes sociais, canais de televisão, rádio e mídia impressa.

Como afirma o autor da reportagem por nós analisada,

Mal haviam chegado e a notícia de sua [de Michael Jackson] morte iminente - finalmente declarada às $14 \mathrm{~h} 26$ - já causava comoção global. O tráfego do serviço de microblogs Twitter dobrou. $\mathrm{O}$ Google entrou em pane, tantas as buscas. O serviço de mensagens instantâneas da AOL também sofreu um colapso nos Estados Unidos. O iTunes e a Amazon, as maiores lojas virtuais de música do mundo, registraram um aumento extraordinário nas vendas de discos e canções de Jackson. No caso da Amazon, o volume de vendas cresceu incríveis 700 vezes. (MARTINS, 2009, p. 96).

A morte do cantor foi transformada em espetáculo e as cenas desse espetáculo foram produzidas, reproduzidas, recontextualizadas ${ }^{2}$ e transformadas de diferentes modos como forma de informação e de entretenimento. $\mathrm{O}$ acontecimento foi "superdimensionado, transformado em capítulo e consumido como um filme" ou como uma novela, num processo de "espetacularização da vida", que "toma o lugar das tradicionais formas de entretenimento" (PENA, 2006, p. 88).

Essa forma de produção e consumo tem sido constante na "sociedade do espetáculo" na qual vivemos. Debord (2003, p. 8) considera que "Toda a vida das sociedades nas quais reinam as condições modernas de produção se anuncia como uma imensa acumulação de espetáculos. Tudo o que era diretamente vivido se esvai na fumaça da representação". Para o autor, "espetáculo é ao mesmo tempo 
parte da sociedade, a própria sociedade e seu instrumento de unificação" (DEBORD, 2003, p. 9) e tem sua manifestação superficial mais esmagadora nos meios de comunicação de massa que produzem os espetáculos especialmente porque lhes são muito rentáveis.

Sem dúvida, a espetacularização da morte de Michael Jackson foi responsável por elevados índices de audiência na TV e no rádio, de acessos e interaçôes nas redes sociais e de venda de jornais e revistas impressos.

Nesse contexto, e considerando a influência que famosos e a mídia exercem sobre boa parte da população, os efeitos causais e sociais que os textos têm (FAIRCLOUGH, 2003) e a influência que exercem na forma como os leitores representam o mundo, investimos na análise da representação discursiva do ator social Michael Jackson e de sua morte em diferentes gêneros da mídia brasileira. São eles: uma notícia e uma reportagem, do jornalismo informativo $;^{3}$ um editorial, um artigo de opinião e uma carta do leitor, do jornalismo opinativo.

Com essa análise, objetivamos: a) perscrutar quais são as escolhas linguísticodiscursivas feitas pelos produtores dos gêneros selecionados para a representação do ator social Michael Jackson e de sua morte e como elas contribuem para a direção argumentativa do texto e para a produção de efeitos de sentido; b) perquirir se há alguma relação entre o gênero e a forma como a representação se dá; c) investigar, utilizando algumas das variáveis propostas por Fairclough (2003), se os atores sociais são representados ativa ou passivamente, pessoal ou impessoalmente, por nomeação ou classificação, específica ou genericamente e discutir os efeitos de sentido da escolha de determinado modo de representação.

A opção pelos referidos gêneros deve-se ao fato de considerarmos, seguindo Marques de Melo (2003), que eles representam os quatro núcleos a partir dos quais se constitui a valoração dos acontecimentos: a reportagem e a notícia representam o núcleo-jornalista; o editorial, o núcleo-empresa; o artigo de opinião, o núcleo-colaborador; e a carta do leitor, o núcleo-leitor. Essa escolha de distintos gêneros também se deve ao fato de acreditarmos que as representações de um fato ou acontecimento e dos atores sociais envolvidos podem ser realizadas de maneira diferente em gêneros distintos.

Com relação à seleção de jornais e revistas, concordamos com Mautner (2008) que são uma rica fonte de dados para projetos em Ciência Social e que pelo menos a mídia de grande circulação "reflete muito a tendência social dominante (ou uma tendência, já que em sociedades pluralistas, geralmente há mais de uma)” (MAUTNER, 2008, p. 32 - tradução nossa). 
Para a análise, apoiamo-nos nos pressupostos da Análise de Discurso Crítica (ADC). Centramo-nos na proposta de Fairclough (2003), no que diz respeito ao significado representacional e na de van Leeuwen (1997) para a análise da representação de atores sociais. Além disso, baseamo-nos em estudos sobre os gêneros da esfera jornalística (MARQUES DE MELO, 2003; DIAS et al, 1998; SEIXAS, 2009) e sobre o discurso da mídia e jornalístico (FAIRCLOUGH, 1995; RICHARDSON, 2007).

A metodologia adotada é de natureza quali-quantitativa e de cunho analítico-descritivo. Durante o desenvolvimento da pesquisa a que este artigo se refere, percebemos que os dados quantitativos poderiam ser úteis à compreensão do objeto de investigação e à interpretação dos dados. Assim, recorremos à integração da pesquisa qualitativa e quantitativa, porque ela "permite que o pesquisador faça um cruzamento de suas conclusōes de modo a ter maior confiança que seus dados não são produto de um procedimento específico ou de alguma situação particular" (GOLDENBERG, 2001, p. 62).

No estudo, investigamos: as escolhas lexicais usadas para a construção da representação do fato e do ator social; algumas das variáveis propostas por Fairclough (2003), com base em Van Leeuwen (1997), para a representação de atores sociais, a saber: nomeação/classificação, especificação/generalização, ativação/passivação, pessoalização/impessoalização; as vozes incluídas e atribuídas especificamente nos textos e como atuam na construção de representações do fato e do ator social.

Queremos deixar claro que nosso foco é na análise dos textos e não da recepção dos textos. Conforme explica Fairclough (1995), a tendência nos estudos sobre a mídia tem sido a análise da recepção dos textos pelo público e não a análise de textos. Nesse sentido, muitos analistas das mídias apresentam objeçôes à análise da linguagem, por considerar que ela coloca uma ênfase indevida na análise de textos e postula significados e efeitos sem levar em conta como os textos realmente são recebidos pelo público (FAIRCLOUGH, 1995).

Sem dúvida, os estudos sobre a recepção de textos para a compreensão de seus sentidos e efeitos são de suma importância, mas também consideramos inegável a importância da análise linguística e discursiva dos textos. Seguindo Fairclough (1995, p.16), cremos que "a análise da linguagem pode ajudar a ancorar a pesquisa e análise cultural e social em uma compreensão aprofundada da natureza do material produzido pela mídia”. No entanto, como ele defende, 
"somente uma análise que considere a linguagem da mídia como discurso e a análise linguística da mídia como parte da análise discursiva é capaz de dar essa contribuição" (tradução nossa). Nessa perspectiva, investimos em uma análise que leve em conta a prática social, a prática discursiva e a prática textual.

Para apresentação deste recorte de nossa pesquisa, organizamos este artigo em quatro partes, além da introdução e da conclusão. Na primeira, apresentamos uma visão geral da Análise de Discurso Crítica. Na segunda, tecemos considerações sobre a mídia, o discurso jornalístico e sobre a prática discursiva da qual os textos selecionados fazem parte. $\mathrm{Na}$ terceira, focalizamos especialmente os modos de representação do fato e do ator social Michael Jackson nos gêneros e, na quarta, analisamos as vozes incluídas e atribuídas especificamente nos textos.

\section{Análise de discurso crítica}

Há aproximadamente vinte e cinco anos, a Análise de Discurso Crítica (ADC) começou a se desenvolver como uma área acadêmica distinta (FAIRCLOUGH, 2006). Em 1985, o termo ADC foi cunhado pelo linguista britânico Norman Fairclough, da Universidade de Lancaster, no seu artigo Critical and descriptive goals in discourse analysis, publicado no Journal of Pragmatics. E, nos anos 90, uma rede de estudiosos formou-se, todos interessados nessa perspectiva teórica.

Como mostram Wodak e Meyer (2001) e Fairclough e Wodak (1997), a ADC inclui diferentes abordagens, as quais, independentemente das diferenças, têm a preocupação de assegurar mais atenção, na pesquisa social crítica, "ao 'discurso' como uma faceta da vida social e à sua relação com outras facetas da vida social” (FAIRCLOUGH, 2006, p. 9).

A ADC volta-se especialmente para a análise das relações dialéticas entre o discurso (incluindo a linguagem verbal e as outras formas de semiose) e outros elementos das práticas sociais. ${ }^{4}$ Nessa perspectiva, entende-se que o discurso é constitutivo dessas práticas e da vida social e é, "portanto, um aspecto significativo (embora muitas vezes negligenciado) das principais questões na pesquisa científica social" (FAIRCLOUGH, 2006, p. 9). Ele é moldado pela sociedade ao mesmo tempo em que a molda em todos os níveis; representa o mundo ao mesmo tempo em que o significa. 
Fairclough (2003) utiliza o termo discurso em dois sentidos: 1) abstratamente, como um nome abstrato, significando linguagem e outros tipos de semiose como elementos da vida social e das práticas sociais; 2) mais concretamente, como um nome contável, significando modos particulares de representar parte do mundo.

Ele postula a existência de três principais tipos de significado do texto: o acional, o representacional e o identificacional. Esses três tipos de significado são por Fairclough (2003) relacionados respectivamente aos elementos das ordens do discurso ${ }^{5}$ - gêneros, discursos e estilos - e aos três modos principais pelos quais o discurso figura como uma parte da prática social: modos de agir (gêneros); modos de representar (discursos - $2^{\circ}$ sentido); e modos de ser (estilos). O autor defende que focalizar a análise de textos na interação desses três significados traz uma perspectiva social para a essência do texto.

Dado o enfoque de nosso estudo, tecemos considerações apenas sobre os significados acional e representacional.

\subsection{Discurso como ação e interação: os gêneros da esfera jornalística e a intertexualidade}

Fairclough apoia-se em Bakhtin para conceituar gênero do discurso e, em Fairclough (2001a), usa o termo 'gênero' para se referir a um conjunto de convenções relativamente estável que é associado com, e parcialmente representa, um tipo de atividade socialmente aprovado, como a conversa informal, uma entrevista de emprego, um poema ou um artigo científico. Ele argumenta que um gênero implica não somente um tipo particular de texto, mas também processos particulares de produção, distribuição e consumo de textos. ${ }^{6}$

Em sua obra de 2003, Fairclough associa o significado acional ao conceito de gêneros como sendo

os aspectos especificamente discursivos de modos de agir e interagir no curso de eventos sociais: nós poderíamos dizer que (inter)agir nunca é apenas discurso, mas é em geral principalmente discurso. Assim, quando analisamos um texto ou interação em termos de gênero, nós estamos perguntando como ele figura dentro e contribui para a ação social e interação em eventos sociais. (FAIRCLOUGH, 2003, p. 65). 
Nessa perspectiva, os gêneros são definidos pelas práticas sociais a que se relacionam e pelas formas como elas são articuladas.

Os gêneros selecionados para este estudo vinculam-se à prática social jornalística e constituem uma forma de ação e de interação. Eles constroem opiniáo e veiculam explícita ou implicitamente uma visão sobre eventos e, principalmente, pessoas. Assim, aquilo que é veiculado por eles desempenha importante papel social e político, uma vez que é constitutivo da realidade e ao mesmo tempo constituído por ela.

Dada a importância e a influência da mídia na vida das pessoas e na sociedade como um todo, a tarefa de identificação, caracterização e análise dos gêneros da esfera jornalística tem atraído pesquisadores de diversas áreas.

No campo da Comunicação Social, os estudos de Marques de Melo (1985, 2003) sobre os gêneros da esfera jornalística merecem especial atenção. O autor, levando em consideração a questão da fronteira entre informação e opinião e os dados que obteve com a análise de jornais, apresenta dois tipos de jornalismo: informativo e opinativo. Dentro da categoria "jornalismo informativo", inclui o que ele chama de formato: nota, notícia, reportagem e entrevista; e, da categoria opinativo: editorial, comentário, artigo, resenha, coluna, crônica, caricatura e carta. ${ }^{7}$

É importante ressaltar que não concordamos com a designação de formatos, ${ }^{8}$ como propõe Marques de Melo, para categorias como notícia, artigo, editorial, nota, pois tais categorias correspondem, na verdade, a tipos relativamente estáveis de enunciados, elaborados na esfera social jornalística e caracterizados pelo conteúdo temático, estilo verbal e estrutura composicional (BAKHTIN, 2003). Dessa forma são, seguindo este autor, gêneros do discurso.

$\mathrm{Na}$ mesma perspectiva, não concordamos com Marques de Melo quando chama de gênero categorias como informativo, opinativo, utilitário, pois elas correspondem ao foco do jornalismo - informação, opinião, serviço, etc. - e agrupam vários gêneros. Não são, segundo Bakhtin e Fairclough, gêneros do discurso. A ação e a interação na prática social jornalística se dão por meio de notas, notícias, editoriais, artigos de opinião, cartas do leitor, etc, que podem materializar, por exemplo, uma informação, uma opinião, ou ambos.

Não é possível associar o informativo ou o opinativo a um só tipo de atividade socialmente aprovado e a um único processo de produção, pois sabemos, por exemplo, que a notícia representa um modo de ação diferente da reportagem e o processo de produção dos dois gêneros é distinto. Isso também 
pode ser dito com relação a uma carta do leitor e a um editorial. Portanto, categorias como informativo, opinativo e interpretativo não são gêneros para nós. Seixas (2009), do campo da Linguística, adota posição semelhante a nossa.

$\mathrm{Na}$ análise dos dados apresentada no item 3 deste artigo, tecemos breves consideraçôes sobre os gêneros que compóem o corpus deste recorte de nossa pesquisa, a saber: notícia, reportagem, editorial, artigo de opinião e carta do leitor.

Acreditamos que a análise de um exemplar de cada um desses gêneros publicados em diferentes meios de comunicação pode nos fornecer uma amostra de como um mesmo fato e um mesmo ator social foram representados sob diferentes perspectivas: da empresa jornalística, de um colaborador e de um leitor.

Dentre as categorias de análise dos gêneros propostas por Fairclough (2003), associadas ao significado acional, selecionamos para este estudo a intertextualidade, pela produtividade de investigar quais vozes são incluídas nos textos em análise, como são incluídas e como atuam na construção de representações do fato e do ator social.

O termo intertextualidade foi cunhado por Julia Kristeva (1974 [1969]), com base nas obras do Círculo Bakhtiniano. Para Kristeva (1974, p. 64), “(...) todo texto se constrói como mosaico de citaçōes, todo texto é absorção e transformação de um outro texto". No mesmo sentido, Fairclough (2001a, p.114) define a intertextualidade como sendo "a propriedade que têm os textos de ser cheios de fragmentos de outros textos, que podem ser delimitados explicitamente ou mesclados e que o texto pode assimilar, contradizer, ecoar ironicamente, e assim por diante".

Em Fairclough (2003), o autor associa os conceitos de intertextualidade e de polifonia, pois se refere àquela como um processo de articulação e de incorporação em um texto de outros textos e de outras vozes. Segundo ele, a intertextualidade de um texto diz respeito à "presença dentro dele de elementos de outros textos (e por conseguinte outras vozes que não a do próprio autor)" (FAIRCLOUGH, 2003, p. 218). E, na análise dessa categoria, uma questão inicial significante é: "quais textos e vozes são incluídos e quais são excluídos, e quais ausências significativas há no texto?” (FAIRCLOUGH, 2003, p. 47).

Esses textos e vozes podem estabelecer várias relaçōes com o texto no qual foram inseridos e com a voz do autor. Como Bakhtin (1986, p. 69) observa, a relação de um enunciado com outros pode ser em termos de 'capitalizar sobre' eles, 'polemizar com' eles, ou simplesmente 'presumir que já são conhecidos do 
ouvinte'. Nesse sentido, as vozes e os textos presentes em um texto podem também representar perspectivas diferentes, ou não, e a relação entre elas pode ser de complementação ou de embate, numa tensão entre o texto que relata e o relatado.

Para Fairclough, a forma mais comum de intertextualidade é o discurso relatado, o qual pode ou não ser atribuído a vozes específicas. Ele explica que o discurso pode ser relatado de vários modos, como por meio do discurso direto e do indireto. ${ }^{9}$

Neste estudo, como dissemos, observamos quais são as vozes incluídas, recontextualizadas e articuladas nos textos e como atuam na construção de representações do fato e do ator social.

\subsection{Discurso e representação}

Quanto ao significado representacional, ele é relacionado ao conceito de discursos "como modos de representar aspectos do mundo - os processos, relaçôes e estruturas do mundo material, o 'mundo mental' dos pensamentos, sentimentos, crenças, etc, e o mundo social” (FAIRCLOUGH, 2003, p. 124). Tais aspectos podem ser representados diferentemente, de acordo com a perspectiva de mundo adotada. Conforme Fairclough (2001b, p. 2), os discursos são "representações diversas da vida social que são inerentemente posicionadas" e "Em qualquer representação, você tem que decidir o que incluir e excluir, e o que colocar em primeiro e em segundo plano" (FAIRCLOUGH, 1995, p. 4). Assim sendo, olhar para os textos de um ponto de vista representacional implica, segundo Fairclough (2003): observar quais dos elementos dos eventos sociais são incluídos, quais são excluídos na representação desses eventos e quais dos elementos incluídos têm maior proeminência; investigar quais atores sociais são excluídos, quais são incluídos e como são incluídos.

Fairclough (2003) estabelece um diálogo com van Leeuwen (1997) para tratar da representação de atores sociais. Este autor fornece um "inventário sóciosemântico dos modos pelos quais os actores sociais podem ser representados" (VAN LEEUWEN, 1997, p. 169), além das diferentes possibilidades de realização linguística dessas representaçōes.

Van Leeuwen destaca a importância de se olhar tanto para o linguístico quanto para o sociológico e apresenta uma rede de sistemas que abrange uma 
variedade de fenômenos linguísticos e retóricos, tendo como elemento centralizador o conceito de ator social. Ele argumenta que "As representações incluem ou excluem actores sociais para servir os seus interesses e propósitos em relação aos leitores a quem se dirigem." (VAN LEEUWEN, 1997, p. 180).

Os textos em análise neste artigo, por exemplo, encerram especialmente uma representação da morte do cantor Michael Jackson e/ou desse ator social. Ao produzir um texto sobre esse fato e esse ator social, os jornalistas/produtores fazem escolhas acerca do que incluir e do que excluir. Essas escolhas estão atreladas a interesses e propósitos.

$\mathrm{Na}$ rede de sistema referente à representação de atores sociais no discurso, Van Leeuwen (1997) apresenta mais de quinze categorias associadas à inclusão e duas atreladas à exclusão. Tais categorias dizem respeito não somente à representação linguística como também à discursiva e à social.

Partindo dessa rede, Fairclough (2003, p. 145-6) registra as escolhas disponíveis para a representação de atores sociais em termos de sete variáveis: inclusão/exclusão, pronome/nome, papel gramatical, ativo/ passivo, pessoal/ impessoal, nomeado/classificado, específico/genérico. Delas, optamos por trabalhar apenas com a inclusão e com estas quatro variáveis a ela associadas: ativação/passivação; pessoalização/impessoalização; nomeação/classificação; especificação/generalização.

No item 3 deste artigo, em que apresentamos a análise da representação do ator social Michael Jackson, discorremos sobre essas quatro variáveis.

\section{Mídia, discurso jornalístico e prática discursiva: análise da produção, da distribuição e do consumo dos textos selecionados}

É consabido que, nos dias atuais, as mídias impressa, eletrônica e digital representam as principais fontes de informação e entretenimento nas diferentes classes sociais. Assim, aquilo que é veiculado por elas desempenha importante papel na sociedade, uma vez que é constitutivo dela e por ela constituído e influencia o modo como os leitores se representam e representam os outros e o mundo. 
Conforme afirma Motta (2002, p. 16),

as sociedades passaram a ser impulsionadas por uma lógica midiática. A mídia passou a ser a instituição política e ideologicamente mais notável da sociedade, suplantando outros poderes (...) e superando outras instituições poderosas, como a igreja e a escola, na produção e disseminação das ideologias, condicionando tudo à lógica midiática.

Dessa forma, a mídia passou a ser considerada o segundo poder (RAMONET, 1999), exercendo diária e continuamente controle sobre o público, de modo que as pessoas reproduzem, consciente ou inconscientemente, os discursos nela veiculados, perpetuando práticas socioculturais, valores e crenças. Ela estabelece o que deve ou não ser divulgado e como, contribuindo para a construção de uma perspectiva de representação do mundo e dos atores sociais.

Em seu livro Media Discourse, Fairclough (1995) destaca o poder que a mídia tem de influenciar o saber, as crenças, os valores, as relações sociais e as identidades sociais. Ela tem, segundo o autor, um poder significativo de representar as coisas de modos particulares, o que é, em grande parte, uma questão de como a linguagem é usada. Para ele, o trabalho ideológico da linguagem na mídia inclui modos particulares de representar o mundo, construçôes particulares de identidades sociais e de relações sociais. E isso está associado à prática social e à prática discursiva, pois envolve relações de poder, a instituição, crenças, valores, desejos e o discurso/semiose - elementos da prática social (CHOULIARAKI, FAIRCLOUGH, 1999) - e a produção, distribuição e consumo de textos - elementos da prática discursiva (FAIRCLOUGH, 2001a).

Sobre a produção, consumo e distribuição de textos da esfera jornalística, é possível dizer que, apesar de estarmos vivendo um período de muitas mudanças e de compressão do tempo e do espaço, muitos eventos comunicativos nos meios de comunicação, como um documentário televisivo e uma reportagem ou artigo de opinião em uma revista de circulação semanal ou mensal, envolvem grandes separações temporais e espaciais. Isso porque o tempo e o lugar de produção de um documentário, de uma reportagem, de um artigo de opinião, de uma carta do leitor, por exemplo, é diferente do tempo e do espaço de consumo. Esses textos podem ser consumidos em vários momentos e em vários lugares.

Fairclough defende que um evento comunicativo nos meios de comunicação de massa pode ser visto como uma rede de eventos comunicativos 
e que é frutífero conceber o consumo e a produção do texto veiculado nos meios de comunicação "em termos de transformações através de eventos comunicativos encadeados” (FAIRCLOUGH, 1995, p. 50).

Considerando os textos selecionados para análise em nosso estudo, podemos dizer que eles fazem parte de uma rede que compreende os eventos comunicativos que constituem a produção, a distribuição e o consumo de cada um. Essa rede inclui ainda os eventos fonte de cada texto - a morte de Michael Jackson, o que a precedeu e a sucedeu -, as fontes das entrevistas que são recontextualizadas na notícia e na reportagem e os textos que circularam nas diferentes mídias sobre o assunto, transformando-o, muitas vezes, em um espetáculo. Além disso, engloba os eventos subsequentes, como os comentários e pesquisas sobre esses textos e o compartilhamento pelos leitores. Nessa cadeia, os textos primeiramente produzidos sobre o fato podem passar a ser fonte para outros textos.

No tocante ao fato em questão - a morte do cantor Michael Jackson -, percebe-se o grande impacto dos meios de comunicação de massa nas fronteiras entre o público e o privado. A vida e a morte de uma pessoa, que se poderia entender como apenas do domínio privado, tornou-se acessível para consumo privado universal ao ser foco de - e espetáculo em - vários meios de comunicação.

Sobre as práticas institucionais associadas à produção e ao consumo de textos da mídia, Fairclough elucida que um conjunto de rotinas institucionais comandam os processos de produção de textos midiáticos. Esse conjunto engloba rotinas de coleta e seleção de materiais, de edição e transformação de material em textos finais.

Quanto à produção especificamente de gêneros veiculados em jornais e revistas, por exemplo, ela é resultado de um trabalho coletivo, que envolve jornalistas, produtores, vários membros da equipe editorial e da equipe técnica, crenças, valores, relações de poder, a instituição e o discurso/semiose como elementos da prática social jornalística. Várias versões de um mesmo texto são produzidas até que se chegue ao produto final a ser publicado, conforme as restrições e interesses associados a essa prática social.

Com relação ao consumo dos textos divulgados nos meios de comunicação, ele também é caracterizado por rotinas e práticas institucionais. Na sua obra de 1995, Fairclough afirma que esses textos são consumidos, esmagadoramente, em contextos de domínio privado, no lar e no contexto da vida familiar. Porém, acreditamos que isso tenha mudado um pouco, pois, nos dias atuais, observamos que programas televisivos podem, por exemplo, ser vistos pela TV, nas salas de 
espera de consultórios e aeroportos, e pelo computador em qualquer domínio e em diferentes espaços.

Independentemente dessa mudança, os media continuam a definir para a maioria da população os acontecimentos significativos que estão a ter lugar, mas também oferecem interpretações poderosas acerca da forma de compreender estes acontecimentos. Como afirma Bourdieu (1997, p. 25-26), “Os jornalistas têm óculos especiais a partir dos quais veem certas coisas e não outras; e veem de certa maneira as coisas que veem. Eles operam uma seleção e uma construção do que é selecionado. O princípio da seleção é a busca do sensacional, do espetacular.".

Nessa perspectiva, destacamos a relevância de investigar as escolhas presentes nos textos para a representação de fatos e de atores sociais, pois elas exercem grande influência na forma como os leitores compreendem esses fatos e identificam os atores neles envolvidos. Assim, é importante que os leitores tenham acesso a vários textos, de vários gêneros, sobre um mesmo assunto, comparem as representações construídas neles, para que não vejam o mundo apenas pelas lentes dos óculos de um só jornalista e de um só meio de comunicação.

\section{A representação do ator social Michael Jackson e do fato de sua morte}

Inicialmente, destacamos que, no recorte que aqui apresentamos, não trabalhamos com as referências ao ator social realizadas por pronomes pessoais, mas apenas com as materializadas por meio de grupos nominais e verbais.

Este recorte do corpus é composto por textos publicados imediatamente após a morte do cantor Michael Jackson. São eles: a notícia "Michael Jackson morre aos 50 anos", publicada no dia 26 de junho de 2009 pelo $O$ Globo; a reportagem "Uma lenda envolta em mistério, dentro de um enigma" da revista Veja, do dia $1^{\circ}$ de julho de 2009; o editorial "Michael Jackson" da Folha de S. Paulo, de 27 de junho de 2009; o artigo de opinião "O mundo chora a morte de Michael Jackson”, publicado em 26 de junho de 2009 pelo $O$ Globo; e a carta do leitor do dia 8 de julho de 2009, enviada por César Caldas para a revista Veja.

Antes de iniciar a análise, apresento breves considerações sobre cada um desses gêneros. A notícia "é um relato integral de um fato que já eclodiu no organismo social” (MARQUES DE MELO, 2003, p. 66). Esse relato "parte do 
aspecto mais relevante que o fato possui” (COSTA, 2008, p.11). Já a reportagem "é o relato ampliado de um acontecimento que já repercutiu no organismo social e produziu alterações que já são percebidas pela instituição jornalística” (MARQUES DE MELO, 2003, p. 66). É um gênero que aborda um tema de forma mais aprofundada, "apresentando impactos, contexto, desdobramentos e antecedentes" (COSTA, 2008, p.11) e não se limitando à mera descrição do fato. Quanto ao editorial, ele é assim definido por Nascimento (2003, p. 85):

um texto argumentativo que representa a opinião da empresa jornalística que o publica. Através dele, é apresentado o posicionamento do jornal sobre fatos do dia-a-dia. A partir de um fato, o(a) editoralista desenvolve um raciocínio valorativo, através do qual defende, com argumentos persuasivos, a posição político-social do jornal e refuta as opostas, conduzindo o leitor à conclusão pretendida pela empresa.

O gênero artigo de opinião, por sua vez, é concebido por Marques de Melo como um gênero da esfera jornalística que representa um tipo de matéria escrita, na maioria das vezes, por um colaborador do jornal, convidado pela organização para expor seu ponto de vista sobre determinado assunto de sua competência, da atualidade jornalística. Esse colaborador pode ser fixo, eventual ou às vezes espontâneo.

No que diz respeito ao gênero carta do leitor, ele é considerado um "espaço em certo sentido democrático, ao qual cada um pode recorrer" (MARQUES DE MELO, 1985, p. 129). Porém, o espaço não é totalmente democrático, pois a opinião do público ainda passa pela avaliação da empresa jornalística. Esse gênero circula no contexto jornalístico, em seção fixa de revistas e jornais, reservada à correspondência dos leitores. Ele atende a "diversos propósitos comunicativos: opinar, agradecer, reclamar, solicitar, elogiar, criticar, entre outros. É um gênero do domínio público, de caráter aberto, com o objetivo de divulgar seu conteúdo, possibilitando, assim, ao público em geral a sua leitura". (BEZERRA, 2002, p. 210).

No que concerne à análise da representação do fato - a morte de Michael Jackson - nesses gêneros, identificamos 18 (dezoito) realizações, materializadas por diferentes escolhas nos gêneros notícia, reportagem, editorial e artigo de opiniāo. E, na carta do leitor, nenhuma ocorrência. Seu produtor apresentou sua opiniāo apenas sobre o ator social Michael Jackson. 
A escolha lexical "morte" aparece em 12 (doze) das 18 (dezoito) ocorrências. Na notícia, provavelmente por ser um texto mais curto e mais objetivo, há apenas uma ocorrência de representação do fato. O gênero focaliza a informação sobre o fato e suas possíveis causas. Na reportagem, com 07 (sete) ocorrências, os produtores apresentaram a trajetória percorrida por Michael Jackson em sua vida pessoal e profissional, destacaram os reflexos do ocorrido no mundo e a condição de imprevisibilidade da morte de Michael Jackson, com os modificadores "súbita" e "iminente" do nome-núcleo "morte", presentes em duas ocorrências, conforme excertos a seguir:

(1) "Mal haviam chegado e a notícia de sua morte iminente (...) já causava comoção global." (p. 98); "Morte súbita” (p.99) - reportagem;

Essa condição de imprevisibilidade também foi marcada no editorial, por meio da escolha do modificador "repentina" para o nome "morte", em:

(2) "Não é apenas pelo talento incomum de Michael Jackson nem pela comoção mundial provocada por sua morte repentina, que a dramática trajetória do cantor americano suscita comentário neste espaço." (p. 4) - editorial.

No artigo de opinião, o produtor tratou o fato de maneira sensibilizada e enfatizou o sentimento de perda e dor provocado pela morte, em trechos como:

(3) "o mundo chora a morte de Michael Jackson"; "os Estados Unidos e o mundo choram a perda do grande ícone da música pop"; "existem fatos inexplicáveis neste triste acontecimento"; "Deus o levou para junto dele; não está mais entre nós"; "nos deixa não somente a dor da perda"; "o mundo chora por sua morte"; "o mundo perde um artista como poucos".

No que diz respeito à representação do ator social Michael Jackson, focalizamos as escolhas linguístico-discursivas feitas pelos produtores dos textos e as variáveis selecionadas para análise dessa representação, a saber: nomeação/ classificação, especificação/generalização, ativação/passivação, pessoalização/ impessoalização.

Com relação à variável nomeação/classificação, observa-se se os atores sociais são nomeados (representados pelo nome) ou classificados (representados em termos de classe ou categoria - ex. "o cantor"). Segundo Van Leeuwen (1997, p. 200), 
"os atores sociais podem ser representados quer em termos da sua identidade única, sendo nomeados, quer em termos de identidades e funçōes que partilham com outros (categorização)" (VAN LEEUWEN, 1997, p. 200). De acordo com o interesse do sujeito produtor, os atores sociais podem ter explícitos os seus nomes, acompanhados ou não de modificadores, bem como podem ser identificados apenas pela função e/ou profissão que exercem na sociedade. No título da notícia em análise, por exemplo, o ator social é representado de modo nomeado "Michael Jackson morre aos 50 anos". O ator social pode, ainda, ser nomeado e ao mesmo tempo, numa oração, ser classificado, como ocorre na notícia " $\underline{O \text { cantor Michael }}$ ذackson, de 50 anos, morreu na tarde desta quinta-feira”.

Essa classificação, segundo Van Leeuwen, pode se dar de modo específico ou genérico. Se os atores são classificados, deve-se verificar se são representados específica ou genericamente: a expressão 'os professores' pode se referir a um grupo específico de professores (ex. aqueles que trabalham em determinada escola ou rede), ou à classe de professores em geral - todos os professores. Na proposta de van Leeuwen (1997), a primeira corresponde aos participantes representados como indivíduos específicos e identificáveis (referência específica) e, a segunda, aos atores sociais referidos como classes (referência genérica).

Como exemplo de representação de modo específico e de modo genérico, podemos citar dois trechos da reportagem em análise: "O cantor começou a usar remédios para a dor em meados dos anos 80" (específico); "Tenho orgulho de ser um negro americano" (genérico).

Em seu livro centrado na análise da linguagem jornalística com base na ADC, Richardson (2007) trata da importância da nomeação e da referência ${ }^{10}$. Ele acredita que o modo como os atores sociais são nomeados no discurso jornalístico "pode ter um impacto significativo no modo como eles são vistos." e que "as estratégias referenciais escolhidas pelo produtor (...) não projetam apenas significados e valores sociais para o referente. Elas também estabelecem relações de coerência com a forma como os outros atores sociais são referidos e representados" (RICHARDSON, 2007, p. 49-50 - tradução nossa).

No artigo de opinião em análise, por exemplo, o produtor faz escolhas para a representação do ator Michael Jackson que projetam valores que colocam Jackson numa posição de superioridade em relação a muitos artistas e cantores, como nos trechos: "os Estados Unidos e o mundo choram a perda do grande ícone da música pop"; "o cantor se tornou uma das figuras mais conhecidas e adoradas da música norte-americana, tornando-se um verdadeiro ícone da música 
pop"; "o mundo perde um artista como poucos". Além de essas escolhas constituírem uma referência a Michael Jackson e uma representação desse ator social, indicam uma relação com a forma como outros artistas e cantores são referidos e representados.

Como se pode ver, essas estratégias referenciais também trazem marcas de juízos de valor e Richardson destaca a relevância de se analisar, nos textos jornalísticos, "a escolha de palavras usadas para representar mais diretamente os valores e características dos atores sociais” (RICHARDSON, 2007, p. 52 tradução nossa), o que procuramos contemplar neste estudo.

Para ilustrar essa estratégia, temos, além dos trechos citados presentes no artigo de opinião em análise, alguns exemplos em outros gêneros que compõem o nosso corpus. Em um trecho da notícia, o produtor refere-se ao ator social Michael Jackson como "o astro", em "O astro chegou a receber massagem cardíaca”. Na reportagem, há escolhas como "Michael Jackson foi o primeiro grande ídolo mirim da música”, "Esse Jackson aberrante e patético encobriu o totem da revolução pop”, "O cantor multimilionário, dono dos direitos de 250 canções dos Beatles, acumulou uma dívida avaliada em 500 milhões de dólares”. Em um trecho do editorial, é atribuído a Michael Jackson o predicado de "símbolo inquietante das contradições de nosso tempo" e, na carta do leitor, encontramos referências a ele, como: "Insuperável e insubstituível”.

Em todos esses exemplos, as estratégias referenciais e predicacionais (REISIGIL, WODAK, 2001) trazem marcas de avaliação do ator social por parte de quem produziu os textos e contribuem para a construção de diferentes representaçôes. Pode-se dizer que isso está associado ao que se imagina que o leitor/ ouvinte espera, ao gênero produzido e ao posicionamento político-ideológico do produtor e do meio de comunicação para o qual produz.

No tocante à variável ativação/passivação, ela diz respeito a como os atores sociais são representados - com papéis ativos ou passivos. Van Leeuwen (1997, p. 187) explica que "A activação ocorre quando os actores sociais são representados como forças ativas e dinâmicas numa actvidade, e a passivação quando são representados como 'submetendo-se' à atividade, ou como 'sendo receptores dela". Na reportagem selecionada temos, por exemplo: "Jackson quebrou essa barreira em discos como Off the wall, de 1979, e Thriller, de 1982, e borrou para sempre a linha que separava os dois universos". Neste excerto, Jackson é representado como uma força dinâmica e ativa; é participante ator dos processos materiais "quebrou" e "borrou”. Também temos no artigo de opinião 
selecionado trechos como "Em 1993, o cantor foi acusado de ter molestado sexualmente um menor de idade.”. Nele, há o apagamento do agente da acusação e "o cantor" é representado de modo passivo na oração.

Quanto à variável pessoalização/impessoalização, observa-se se os atores sociais são representados pessoal ou impessoalmente. Van Leeuwen afirma que as escolhas representacionais que personalizam os atores sociais representam-nos como seres humanos. Essa representação é realizada por meio de "pronomes pessoais ou possessivos, nomes próprios ou substantivos (por vezes adjectivos, como, por exemplo, em (...) 'cuidados maternais'), cujo significado inclui a característica 'humana." (VAN LEEUWEN, 1997, p. 208). Os dois últimos excertos citados no parágrafo anterior exemplificam a representação do ator social Michael Jackson de modo pessoal.

Já a impessoalização diz respeito à representação do ator como não humano. Ela pode se dar por meio de substantivos abstratos ou concretos, "cujo significado não inclui característica semântica 'humana" (VAN LEEUWEN, 1997, p. 208). Na reportagem em análise, por exemplo, temos a representação do ator social como "uma lenda" e, no editorial, como "uma espécie de máscara”.

Tendo em vista essas noções gerais de cada variável, que acabamos de expor com base na proposta de Fairclough (2003) construída com base em Van Leeuwen (1997), apresentamos a tabela 1 com os números relativos às ocorrências dos diferentes modos de representação do ator social selecionados:

TABELA 1

Escolhas para a representação do ator social Michael Jackson

\begin{tabular}{l|c|c|c|c|c|c}
\hline \multirow{2}{*}{ TIPO DE ESCOLHA/ GÊNEROS } & & & & & & TOTAL \\
\cline { 2 - 7 } & $\mathrm{N}^{11}$ & $\mathrm{R}$ & $\mathrm{E}$ & $\mathrm{A} 0$ & $\mathrm{CL}$ & \\
\hline Representação por nomeação & 5 & 58 & 7 & 14 & 2 & 86 \\
\hline Representação por classificação: & \multicolumn{5}{|l}{} \\
\cline { 2 - 8 } $\begin{array}{l}\text { a) de modo específico } \\
\text { b) de modo genérico }\end{array}$ & 4 & 42 & 6 & 28 & 6 & 86 \\
\cline { 2 - 8 } & - & 8 & 3 & - & 1 & 12 \\
\hline Representação de modo ativo & 5 & 82 & 11 & 30 & 5 & 133 \\
\hline Representação de modo passivo & 3 & 31 & 4 & 12 & 1 & 51 \\
\hline Representação de modo pessoal & 7 & 119 & 13 & 42 & 5 & 186 \\
\hline Representação de modo impessoal & - & 2 & 1 & - & 1 & 3 \\
\hline
\end{tabular}


Pela tabela 1, pode-se ver que, em número total, predomina a representação por classificação (98) e não por nomeação (86). Contudo, essa prevalência não ocorre em todos os gêneros. Observamos que nos gêneros do jornalismo informativo - notícia e reportagem - há mais nomeação que classificação; nos gêneros do jornalismo opinativo - artigo de opinião e carta do leitor - acontece o contrário; e, no editorial, há quase o mesmo número dos dois modos de representação.

Considerando que, ao classificar o ator social o produtor de um texto deixa mais explícito a sua avaliação e o seu posicionamento que ao nomear, é possível associar essa diferença nos dois modos de representação à maior liberdade de expressão de julgamentos pelos leitores - produtores do artigo e da carta - e a maiores restrições institucionais imprimidas aos jornalistas - produtores da notícia e da reportagem. Nos gêneros que representam os núcleos jornalista e empresa (MARQUES DE MELO, 2003), predomina a nomeação. Já nos que retratam os núcleos colaborador e leitor a classificação aparece como uma escolha prevalecente.

Observa-se que, em todos os gêneros, há mais ocorrências de classificação de modo específico que genérico. Este resultado vem ao encontro do que van Leeuwen afirma sobre a mídia voltada para a classe média, a qual tende, segundo ele, a classificar de modo específico famosos, especialistas e agentes governamentais. Isso produz um efeito de individualizar o ator social e de, assim, não criar uma universalização.

Essa classificação acontece especialmente pela funcionalização e pela avaliação ou valoração (VAN LEEUWEN, 1997). A primeira ocorre quando os atores sociais são referidos em termos de uma ocupação, uma atividade ou de uma função que desempenham. Já a segunda acontece quando os atores sociais são referidos por meio de escolhas que "os qualificam, como bons ou maus, amados ou odiados, admirados ou lamentados” (VAN LEEUWEN, 1997, p. 207).

No gênero notícia, encontramos duas ocorrências de classificação por funcionalização "cantor" e duas por valoração "astro". Na reportagem, há onze classificações por funcionalização do ator social Michael Jackson, todas realizadas por "cantor". Todas as outras 39 (trinta e nove) ocorrências na reportagem expressam uma valoração do ator social e essa escolha contribui significativamente para a construção ora de uma representação positiva/favorável ao ator social, em que são ressaltadas suas qualidades como cantor e inovador da música pop, ora uma representação desfavorável, que evidencia aspectos negativos de sua vida pessoal e profissional. 
A primeira representação é realizada por meio de estratégias referenciais e predicacionais (REISIGL E WODAK, 2001), materializadas por nomesnúcleo e modificadores de expressões nominais utilizadas, tais como: "rei do pop"; "dono dos direitos de 250 cançôes dos Beatles"; "um ícone"; "o primeiro grande ídolo mirim da música”; "o filho-prodígio"; "o cantor multimilionário"; "artista virtuoso"; "grande"; "um artista curioso e vivo".

Já para a valoração e representação negativa na reportagem, colaboram escolhas como: "aberrante e patético"; "no personagem Michael"; "pobre Michael"; "cada vez mais esquisito"; "cada vez mais excêntrico"; "feio"; "nem preto, nem branco, nem homem, nem mulher, nem adulto, nem criança"; "a personificação das deformações que a fama é capaz de imprimir, até mesmo fisicamente, em quem vive dela"; "uma fabricação"; "ser humano perturbado"; "cada vez mais esquisito"; "recluso, calado e solitário"; "Esquisitíssima, ambígua e desequilibrada figura"; "feio"; "o artista inacessível"; "o avesso do avesso".

Com relação ao editorial, o ator social é classificado por funcionalização quatro vezes. Nas quatro, a escolha é "cantor". As outras classificações são realizadas por uma valoração do ator social como "Ícone religioso, bizarro e inumano", "ídolo" e como alguém que "No brilho e no drama de sua biografia, (...) se inscreve como um símbolo inquietante das contradições de nosso tempo" e "Parece esvair-se de sua própria identidade, transformando-se numa espécie de máscara."

No gênero editorial, constrói-se uma representação do ator social que enfatiza os dramas vivenciados por Michael Jackson na esfera pública e na privada, sua crise identitária, sua rejeição à "negritude" e uma identificação associada às contradições de nosso tempo. Além das escolhas citadas, contribuem para isso outras que marcam uma avaliação, como: "a dramática trajetória do cantor norte-americano"; "Talvez nenhuma outra figura contemporânea tenha concentrado o conflito entre a esfera pública e a vida pessoal que marca o mundo contemporâneo"; "Durante a própria infância, o cantor conheceu a cisão entre uma rotina de apariçōes felizes diante das câmeras e uma realidade familiar marcada pela violência e exploração"; "um traço tipicamente contemporâneo de sua biografia talvez tenha sido o fato de que a divisão entre êxito público e trauma privado adquiriu, com Michael Jackson, uma tradução visual e midiática.”.

No que diz respeito ao artigo de opinião, nele há uma retrospectiva da vida de Michael Jackson: "Escrevo este artigo tendo como intuito lembrar os grandes momentos, as polêmicas e a trajetória de sucesso que Michael Jackson alcançou em suas quatro décadas de carreira artística”. De fato, 11 (onze) dos 16 (dezesseis) parágrafos que Martins escreve dedicam-se a relembrar os pontos 
positivos e negativos da vida e trajetória de Michael Jackson. Nos demais parágrafos, Martins lamenta profundamente a morte do cantor e avalia que Michael Jackson "foi um verdadeiro astro, um talento", "mas não foi tão grandioso como pessoa", pois "Sua vida foi repleta de escândalos, que por diversas vezes envolviam crianças, inclusive seus próprios filhos.”.

Das 42 (quarenta e duas) referências ao ator social presentes no artigo de opinião, em 28 (vinte e oito) ocorrências, o ator social é classificado. Em dez destas, não há avaliação explícita do produtor, uma vez que apenas categoriza e classifica Michael Jackson por meio da funcionalização realizada pelas escolhas "cantor" (9) e "compositor" (1). Em 18 (dezoito), a classificação ocorre por avaliação, a qual é predominantemente positiva. Há 16 (dezesseis) classificações por avaliação que atuam na construção de uma representação e avaliação positivas de Michael Jackson. Para exemplificá-las, temos: "superastro"; "Convidado da família real do país", "do grande ícone da música pop", "o artista do século"; "uma das figuras mais conhecidas e adoradas da música norteamericana”, "dessa personalidade artística insubstituível, insuperável e eternamente lembrada”, "do 'Rei do Pop' mundial”, "deste gênio e deste mestre da música pop”, "um artista como poucos", etc. Apenas duas constroem uma representação dele que pode ser considerada negativa: "não foi tão grandioso como pessoa" e "um artista de hábitos e atitudes cada vez mais estranhos".

No tocante ao gênero carta do leitor da Veja, seu produtor enalteceu Michael Jackson, utilizando-se de sete classificações. Delas, quatro se dão por funcionalização: "compositor, cantor, coreógrafo, dançarino"; e três, por avaliação: "insuperável e insubstituível”; "ícone da música”; "O próprio conceito do que é a cultura pop".

Esses dados permitem-nos dizer que o ator social é referido tanto em termos experienciais quanto em termos interpessoais, em todos os gêneros, pois há escolhas relativas ao que ele é/foi na realidade, como seu nome e sua função, e há avaliações, as quais marcam posicionamentos e constroem representações diferentes que aqui dividimos entre positivas e negativas.

No que concerne especificamente à nomeação, é relevante observar as escolhas relativas aos tipos de nomeação. Van Leeuwen (1997) explica que ela se realiza tipicamente por meio de nomes próprios e pode ser formal, semiformal ou informal. No primeiro caso, o ator social é representado apenas pelo sobrenome, com ou sem honoríficos, "Jackson"; no segundo, pelo nome e sobrenome "Michael Jackson" e, no terceiro, pelo nome "Michael". Vejamos como essas escolhas se distribuem nos cinco gêneros: 
TABELA 2

Tipos de nomeação nos cinco gêneros

\begin{tabular}{l|c|c|c|c|c|c}
\hline TIPO DE NOMEAÇÃO/GÊNEROS & $\mathrm{N}$ & $\mathrm{R}$ & $\mathrm{E}$ & $\mathrm{A} 0$ & $\mathrm{CL}$ & TOTAL \\
\hline FORMAL & - & 25 & 01 & 07 & 01 & 34 \\
\hline SEMIFORMAL & 04 & 18 & 06 & 05 & 01 & 34 \\
\hline INFORMAL & 01 & 15 & - & 02 & - & 18 \\
\hline TOTAL & 05 & 58 & 07 & 14 & 02 & 86 \\
\hline
\end{tabular}

Sobre essas escolhas, é importante ressaltar que, pelo fato de a nomeação informal denotar mais intimidade, proximidade e familiaridade do produtor em relação ao ator social, não esperávamos encontrar esse tipo de escolha nos gêneros analisados, especialmente na notícia e na reportagem, materializada na voz de seus produtores. Acreditávamos que esse tipo de realização da nomeação pudesse aparecer nas vozes de amigos e familiares, recontextualizadas nos gêneros analisados. Contudo, o resultado mostrou-nos o oposto. As ocorrências nos gêneros notícia, reportagem e artigo de opinião estão incluídas na voz dos produtores, com exceção de apenas uma, na reportagem, que está presente na voz da mãe de Michael Jackson.

Talvez em função da fama do ator social e do carisma que muitos tinham por ele, a proximidade e familiaridade tenham sido marcadas inclusive nos gêneros do jornalismo informativo.

Ainda pela tabela 1 , percebemos que há um número maior de ocorrências de representação de modo ativo (133) que de modo passivo (51). Predomina uma representação que coloca o ator social como agente e destaca as ações que ele praticou ao longo de sua vida, as quais contribuíram para que ele fosse o ser humano que foi, conhecido mundialmente, quer por aspectos considerados positivos, quer por negativos. Ele "mostrou seu talento para a música e para a dança muito cedo", "lançou dois de seus melhores discos, "Thriller", de 1982, e "Bad", de 1987, e consolidou a posição de superastro", "vendeu em torno de 750 milhões de discos, ganhou 13 Grammys" (artigo de opinião). Também "inventou a música pop", "derrubou uma das últimas barreiras que restavam entre brancos e negros nos Estados Unidos", "Michael Jackson passou a infância trabalhando como um adulto"; "Aos 20 anos, Michael Jackson decidiu exorcizar os fantasmas infantis pela fuga de si mesmo e pela erradicação de sinais visíveis de sua origem. Começou a sua metamorfose"; "usava máscara", "confessou que sim, dormia com garotos na mesma cama" (reportagem). 
Em todos os gêneros analisados, prevalece também a representação de modo pessoal, ou seja, as escolhas representam o ator social Michael Jackson como ser humano, o que nos parece ser algo esperado pelos leitores. Elas são realizadas por "nomes próprios ou substantivos (por vezes adjectivos, como, por exemplo, em 'maternal care' [cuidados maternais]) cujo significado inclui a característica 'humana"' (VAN LEEUWEN, 1997, p. 208). Os exemplos de classificação e de nomeação já citados ilustram esse modo de representação. Quanto ao modo impessoal, ele aparece minimamente no corpus. Consideramos impessoal ocorrências em que o ator social é representado como sendo uma espécie de máscara e uma lenda, por entendermos que o significado desses dois nomes não inclui, necessariamente, a característica semântica humana, conforme propõe Van Leeuwen (1997).

Como vimos, então, foi possível identificar, nos textos dos cinco gêneros da esfera jornalística, diferentes modos de representação do ator social Michael Jackson e diferentes escolhas lexicais, os quais contribuem, sobremodo, para a produção de diferentes sentidos, representações e identificaçōes nos textos.

Considerando que essa produção é também fruto da intertextualidade presente nos textos, analisamos a seguir quais vozes são incluídas e atribuídas especificamente nos gêneros selecionados, qual relação estabelecem com a voz dos produtores e como atuam na construção de representações do fato e do ator social Michael Jackson.

\section{A representação por meio das vozes incluídas e atribuídas especificamente}

$\mathrm{Na}$ análise dos exemplares dos gêneros da esfera jornalística selecionados, não identificamos vozes incluídas e atribuídas especificamente no editorial e na carta do leitor. Apenas nos gêneros do jornalismo informativo - notícia e reportagem - e no artigo de opinião, do jornalismo opinativo, o recurso da intertextualidade manifesta foi utilizado pelos produtores.

$\mathrm{Na}$ notícia, os produtores enunciaram o fato e descreveram como ele aconteceu. E, para fornecer ao leitor motivos pelos quais se desencadeou a parada cardíaca da qual Michael Jackson foi vítima, a voz do advogado da família, Brian Oxman, foi incluída como fonte e argumento de autoridade.

Segundo essa voz incluída, por meio de discurso indireto e direto, conforme excertos (4) e (5) respectivamente, há a possibilidade de Michael 
Jackson ter consumido exageradamente medicamentos prescritos, em razão de uma queda durante um ensaio:

(4) 'Em declaraçôes à 'CNN', Brian Oxman, advogado da família do cantor, sugeriu que Michael Jackson pode ter abusado de remédios prescritos. Segundo o advogado, Michael estava tomando remédios para lesōes em uma vértebra e em uma perna, resultado de uma queda no palco durante ensaios para os shows em Londres."

Considerando que as escolhas que o produtor faz marcam o direcionamento que quer dar ao seu texto, que a notícia é um gênero do jornalismo informativo, cujo foco primeiro é informar, e considerando ainda que, seguindo Fowler (1991), as notícias, longe de refletirem com neutralidade a realidade social e empírica dos fatos, intervêm na construção (fabricação) social da realidade, a seleção da voz do advogado e não de um membro da família de Michael Jackson ou de seu médico para falar das possíveis causas da morte do cantor é significativa.

Em geral as pessoas famosas ou parentes de famosos convocam seus advogados a falar por elas sobre questôes consideradas complexas e que requerem cautela no tratamento, para evitar prejuízos à imagem e comprometimentos legais. Por meio da recontextualização da voz do advogado da família de Michael Jackson na notícia, constrói-se uma representação da morte de Michael Jackson como não natural e do ator social como alguém que supostamente não tinha controle sobre o consumo que fazia de medicamentos, o que pode associá-lo a uma representação de desequilíbrio:

(5) "Se alguém acredita que o caso de Anna Nicole Smith (ex-modelo que morreu em 2007 por uma overdose de medicamentos) foi um abuso (de remédios), isso não é nada comparado com o que ocorreu na vida de Michael Jackson - afirmou Oxman".

Nesse sentido, na notícia há uma mescla de uma representação positiva, construída por meio da escolha da classificação por avaliação do ator social como "o astro" - conforme já mencionamos - e negativa, pela seleção dos dizeres da fonte - o advogado -, ilustrada nos dois excertos anteriores.

Consideramos, seguindo Fowler (1991, p. 4), que a "notícia é uma representação do mundo na linguagem" eque "Não éuma reflexão valorativamente livre sobre os fatos. Há sempre maneiras diferentes de dizer as coisas e elas não são acidentais". Nesse sentido, a seleção da voz do advogado e de parte de seus dizeres constitui também uma 
valoração do fato e do ator social. E essa valoração, na nossa opinião, é negativa. Consequentemente, atua na construção de uma representação também negativa.

Com relação à reportagem, seguindo os padrōes do gênero, os produtores contextualizaram o fato, relacionaram-no a fatos anteriores ocorridos na vida de Michael Jackson e levantaram suspeitas do motivo da sua morte, utilizando-se de diferentes fontes, com cujos textos estabeleceram uma relação intertextual harmônica. Segundo Resende e Ramalho (2006, p. 6),

Quando uma voz 'externa' é articulada em um texto, têm-se (pelo menos) duas vozes que podem representar duas diferentes perspectivas, com seus respectivos interesses, objetivos, etc. A relação entre essas vozes pode ser harmônica, de cooperação, ou pode haver tensão entre o texto que relata e o texto relatado.

Os produtores também descreveram os altos e baixos da carreira de Michael Jackson. Prestigiaram-no como artista e o criticaram como pessoa. Há, na reportagem, como já argumentamos, ora uma representação positiva/favorável ao ator social, em que são ressaltadas suas qualidades como cantor e inovador da música pop, ora uma representaçáo desfavorável, que evidencia aspectos negativos de sua vida pessoal e profissional. Essa mescla foi ilustrada por nós quando analisamos as escolhas para a representação do ator social por classificação, especialmente.

Vimos marcas do posicionamento e valoração dos produtores da reportagem em relação ao ator social, à sua vida e morte, o que contraria o princípio da objetividade preconizado para gêneros do jornalismo informativo e destaca a impossibilidade de neutralidade na produção de qualquer gênero. Segundo Seixas (2009, p. 80), "O jornalismo de informação é, em última instância, o que se considera na teoria americana o paradigma da objetividade, caracterizado pela separação entre fato e opinião". Vimos que essa separação não ocorreu no exemplar do gênero reportagem analisado.

O posicionamento e a avaliação dos produtores da reportagem podem ser percebidos também pelas escolhas das vozes incluídas no texto, atribuídas especificamente, e do conteúdo de seus dizeres.

Em função da extensão e especificidades do gênero reportagem, é comum encontrarmos nele várias vozes articuladas. Isso acontece no exemplo desse gênero selecionado por nós. E, por haver várias vozes incluídas e atribuídas especificamente, optamos por apresentá-las em um quadro, para melhor visualização: 


\section{QUADRO 1}

As vozes incluídas na reportagem

\begin{tabular}{l|l}
\hline $\begin{array}{l}\text { Vozes incluídas e } \\
\text { atribuídas especificamente }\end{array}$ & Rep \\
\hline Parentes e amigos do cantor &
\end{tabular}

Reportagem

\begin{tabular}{l|l} 
& vinha abusando de analgésicos potentes". (p. 98) \\
\hline TMZ (canal de fofocas) & "Segundo aventou na sexta-feira o canal de fofocas TMZ, entre eles [analgésicos
\end{tabular} potentes que o cantor supostamente estava tomando] estaria o demerol, um opiáceo sintético de ação similar à da morfina. Jackson teria tomado uma injeção poucas horas antes da parada cardíaca”. (p. 98)

\begin{tabular}{l|l}
\hline Irimar de Paula Posso & "Se ele [meperidina, como é chamado o princípio ativo do demerol] for
\end{tabular} (anestesista do Hospital consumido todos os dias, bastam duas semanas para o efeito do medicamento das Clínicas de São Paulo) durar a metade disso’, diz Irimar de Paula Posso, anestesiologista”. (p.98) Joseph Jackson (o pai "Em uma rara entrevista dada à revista Time, descreveu o filho mais famoso: de Michael) 'Ele é muito tímido. Quer dizer, tímido diante de poucas pessoas. No palco, na frente de milhares, ele se solta. O rapaz adora animais. Tem um lhama, dois cervos, um carneiro, uma cobra, três papagaios, dois casais de cisnes, um negro e um branco, alguns pavões. É religioso (mais do que os irmãos) e vegetariano radical. Tem um carrinho de pipoca e uma máquina de fazer sorvete - e sempre convida crianças para compartilhar com ele essas delícias"”; (p.106) "Jackson pai dizia que o filho-prodígio era feio, criticava o rosto com espinhas e ria de seu nariz 'enorme”". (p. 106)

\begin{tabular}{l|l}
\hline Katherine (a mãe) & $\begin{array}{l}\text { "A certa altura, a mãe, Katherine, interrompe: 'Falam que ele é gay. } \\
\text { Michael não é gay. Isso iria contra a religião, contra Deus”. (p. 106) }\end{array}$ \\
\hline Michael Jackson & “'Às vezes, olhava para fora, via as crianças brincando e chorava',contou em
\end{tabular}
entrevista à apresentadora Oprah"; "Lembrou Michael na entrevista a Oprah: 'Ele [o pai] partia para cima da gente... Ficávamos muito nervosos nos ensaios porque ele ficava sentado numa cadeira, com o cinto na mão, e se alguma coisa não saía direito ele vinha para cima, sem dó"”; "De tão aterrorizado, 'tinha vezes que ele [o pai] chegava perto e eu vomitava"'; "ele "chorava todos os dias"”; "A uma admirada Oprah, ele disse candidamente que sua pele ficara branca em consequência do vitiligo, a despigmentação benigna da epiderme. 'É de família', disse"; "Aproveitou para justificar a maquiagem pesada - 'Uso para disfarçar as manchas na pele' - e para reiterar suas raízes: 'Tenho orgulho de ser um negro americano" ; "Não posso acreditar que isso [processo contra Jackson por abuso sexual] esteja acontecendo comigo', lamuriou-se, com um fio de voz"; "Desculpou-se depois, mas afirmou: 'Ele [bebê Blanket ao ser balançado do lado de fora da sacada de um hotel em Berlim] se divertiu"; "'Para Blanket, usei uma mãe de aluguel e meu próprio esperma. Também meus outros dois filhos são do meu esperma. São todos meus filhos', declarou ao inglês Martin Bashir em 2003"; "confessou que sim, dormia com garotos na mesma cama. Inocentissimamente. E recomendou: 'É o que todo mundo devia fazer'”.

Lisa Marie Presley (a filha de Elvis, com quem foi casado durante dois anos)

"ela [Lisa Presley] escreveu num blog: 'Nossa relação não foi uma simulação. Era uma relação incomum, é verdade, na qual duas pessoas incomuns que não tinham nem conheciam uma vida normal encontraram uma conexão". 
Por meio do quadro 1 , pode-se perceber que na reportagem são incluídas vozes de parentes e amigos do cantor, do TMZ (canal de fofocas), do anestesista do hospital onde Michael Jackson foi atendido, do pai, da mãe e da filha dele e do próprio Michael Jackson. As três primeiras vozes citadas e representadas por meio de discurso indireto (duas primeiras) e direto (terceira) especulam o motivo da morte de Michael Jackson: "sugerem que Jackson vinha abusando de analgésicos potentes" e divulgam quais seriam os analgésicos dos quais ele estaria abusando.

Já as vozes do pai - recontextualizadas por discurso direto e indireto - e da mãe - articulada por discurso direto - trazem uma descrição do ator social, em que predominam escolhas que denotam uma atitude de defesa do filho, uma vez que remetem a muito do que é considerado um valor positivo em nossa sociedade, como: a) gostar de animais - "O rapaz adora animais. Tem um lhama, dois cervos, um carneiro, uma cobra, três papagaios, dois casais de cisnes, um negro e um branco, alguns pavões"; b) ser vegetariano e religioso- "É religioso (mais do que os irmãos) e vegetariano radical"; c) ser heterossexual - "Falam que ele é gay. Michael não é gay. Isso iria contra a religião, contra Deus"..

Além disso, neste trecho da fala do pai "Tem um carrinho de pipoca e uma máquina de fazer sorvete - e sempre convida crianças para compartilhar com ele essas delícias", pode-se inferir a construção de uma representação do ator social como um adulto que procurava realizar seus desejos da infância. Tal representação favorece a imagem do cantor, retratando-o como alguém que acreditava no velho dito: "Nunca é tarde demais para ser feliz" e perseguia seus sonhos sem medo da exposição pública.

É relevante destacar ainda um dos trechos da fala do pai relatado pelos produtores da reportagem: "dizia que o filho-prodígio era feio, criticava o rosto com espinhas e ria de seu nariz 'enorme', pois sinaliza um conflito entre pai e filho, o qual foi por várias vezes mencionado em diferentes meios de comunicação. ${ }^{12}$ Esse dizer do pai associado ao que fora publicado sobre ele durante a carreira de Michael Jackson coopera para a construção de uma representação desse ator social como vítima das agressōes não só físicas como verbais do pai, e colabora para justificar os atos do cantor com relação a sua mudança constante de aparência. Michael poderia estar, ainda que inconscientemente, em busca da aprovação do pai.

Essa representação de Michael Jackson como vítima das agressões do pai é reforçada pela inclusão da voz do próprio Michael Jackson, articulada 
predominantemente por discurso direto, e pela seleção de seus dizeres, especialmente em: "Ele [o pai] partia para cima da gente. Ficávamos muito nervosos nos ensaios porque ele ficava sentado numa cadeira, com o cinto na mão, e se alguma coisa não saía direito ele vinha para cima, sem dó"; "tinha vezes que ele [o pai] chegava perto e eu vomitava".

Ainda sobre a inclusão da voz do ator social Michael Jackson, observa-se que sua identificação e representação são enfraquecidas, uma vez que são atreladas a sofrimento, doença, acusação de abuso sexual e a atitudes consideradas incomuns em nossa sociedade, como nos trechos a seguir: "Às vezes, olhava para fora, via as crianças brincando e chorava"; "chorava todos os dias"; "A uma admirada Oprah, ele disse candidamente que sua pele ficara branca em consequência do vitiligo, a despigmentação benigna da epiderme. 'É de família', disse"; "Não posso acreditar que isso [processo contra Jackson por abuso sexual] esteja acontecendo comigo"; "confessou que sim, dormia com garotos na mesma cama. Inocentissimamente. E recomendou: 'É o que todo mundo devia fazer'”.

A voz da ex-esposa de Michael Jackson, Lisa Marie Presley, por fim, constitui uma voz de defesa dela mesma e dele, acusados de simularem o relacionamento que tiveram: "Nossa relação não foi uma simulação. Era uma relação incomum, é verdade, na qual duas pessoas incomuns que não tinham nem conheciam uma vida normal encontraram uma conexão".

A forma como os produtores articularam a voz de Lisa Presley mostra que estabelecem uma relação polêmica com ela, uma vez que deixam marcas de que consideram que o casamento de Lisa Presley com Michael Jackson pode ter sido uma simulação, para minimizar os efeitos negativos das acusações de abuso sexual de menores sobre a reputação do cantor. Essas marcas podem ser percebidas nos excertos (6) e (7) a seguir, pelas escolhas de circunstâncias de modo "sem ter namorado" e "Apressadamente", do adjunto "para surpresa geral", que expressa uma consequência, e por uma valoração por parte do produtor: "nunca convenceu ninguém". Podem ser percebidas também pela inclusão da indicação temporal de duração do casamento, "Durou dois anos", e pela sequência de apresentação dos fatos em (7):

(6) "Em 1994, casou-se sem ter namorado com Lisa Marie Presley, a filha de Elvis. Durou dois anos e nunca convenceu ninguém." (p. 108) 
(7) "Em 1993, quando um esforço para reaquecer a carreira parecia estar dando certo, os pais de Jordan Chandler, 13 anos e hóspede frequente de Neverland, abriram um processo contra Jackson por abuso sexual do filho. "Não posso acreditar que isso esteja acontecendo comigo", lamuriou-se, com um fio de voz. Por 20 milhões de dólares, retiraram a acusação e sumiram, mas a reputação de Jackson desmoronou. Apressadamente, casou-se, para surpresa geral, com Lisa Marie Presley, a filha de Elvis. Divorciou-se dois anos depois e se casou de novo." (p. 110)

Em linhas gerais, por meio da intertextualidade manifesta, os produtores da reportagem incluíram vozes e dizeres que resultam em uma representação que leva o leitor a sentir pena do ator social Michael Jackson, pois destacam suas fragilidades, seus conflitos internos e externos, sua difícil relação com o pai. Essa representação, somada à que predomina na voz dos produtores, coopera para um identificação do ator social marcada por fatos e características valorados, de modo geral, de forma negativa pela sociedade.

No que diz respeito ao artigo de opinião, foram recontextualizados e articulados textos e vozes, como uma estratégia argumentativa para, em alguns momentos, atribuir veracidade aos fatos mencionados no artigo. Há, no artigo, um diálogo com os dados presentes no Guiness Book e nos registros da gravadora Sony e da associação de gravadoras dos Estados Unidos, com a voz de empresários de cantor, conforme excerto 8, e de pessoas não identificadas, como no excerto 9:

(8) "Ao mesmo tempo em que batia recordes de vendas com 'Thriller', que segundo o livro 'Guiness' bateu recorde de vendas, vendeu aproximadamente 55 milhôes (segundo a gravadora Sony e a associação de gravadoras dos EUA) e mais de 100 milhões de cópias (de acordo com empresários do cantor), colocava sucesso atrás de sucesso nos primeiros lugares das paradas e lançava moda entre os adolescentes de todo o mundo com suas roupas e coreografias."

(9) "Em 1993, o cantor foi acusado de ter molestado sexualmente um menor de idade. Segundo relatos da época, Jackson fez um acordo milionário com a família da suposta vítima fora dos tribunais em 1995.”

É relevante observar que essas vozes e textos estabelecem uma relação harmônica com a voz do produtor e cooperam para a defesa da sua opinião acerca do ator social Michael Jackson. Para o produtor, 
O fato é que o mundo perde um artista como poucos, as informaçōes acima citadas resumem a vida desse ícone musical, porque se fôssemos descrever cada acontecimento marcante de sua vida, seria impossível descrever neste artigo. Jackson será eternamente lembrado, seu talento jamais será superado, e mesmo tendo tantas polêmicas em sua vida, tais acontecimentos jamais conseguirão ofuscar o essência deste gênio e deste mestre da música pop (MARTINS, 2009, p. 2).

\section{Considerações finais}

Neste artigo, analisamos como foram representados o ator social Michael Jackson e sua morte em textos veiculados logo após o falecimento do cantor, a saber: uma notícia, uma reportagem, um editorial, um artigo de opinião e uma carta do leitor.

A análise quali-quantitativa dos textos desses gêneros - especificamente a investigação das escolhas lexicais, de algumas das variáveis propostas por Fairclough (2003), com base em Van Leeuwen (1997), usadas para a construção da representação do fato e do ator social, e da intertextualidade manifesta - jogou luz às escolhas presentes nesses textos e aos efeitos dessas escolhas na construção de representações discursivas.

Com relação à representação do fato, predominou a escolha lexical "morte" nos gêneros notícia, reportagem editorial e artigo de opinião, associada, em algumas ocorrências a modificadores; e, na carta do leitor, a representação presente refere-se apenas ao ator social.

No tocante às variáveis para representação de ator social selecionadas, a análise revelou que, em todos os gêneros, a representação de modo ativo e pessoal é dominante. Revelou, ainda, que, nos exemplares dos gêneros do jornalismo informativo, há mais nomeação que classificação; nos gêneros artigo de opinião e carta do leitor - do jornalismo opinativo - acontece o contrário; e que, no editorial, há quase o mesmo número dos dois modos de representação: sete nomeações e seis classificaçóes.

Assim sendo, nos gêneros que representam os núcleos jornalista e empresa - notícia, reportagem e editorial - predomina a nomeação. Já nos que retratam os núcleos colaborador e leitor - artigo de opinião e carta do leitor -, a classificação aparece como uma escolha dominante. 
Sobre a classificação, em todos os gêneros, há mais ocorrências de classificação de modo específico que genérico, o que demarca o ator social, individualizando-o e não criando uma universalização. Essa classificação acontece especialmente pela funcionalização e pela valoração, sendo que a última prevalece nos gêneros e colabora, sobremaneira, para a produção de uma mescla na representação do ator social Michael Jackson.

A análise das escolhas lexicais presentes na voz do produtor da notícia e das variáveis para a representação de ator social, na notícia, delineiam uma identificação positiva do ator social Michael Jackson, o que contrasta com a voz do advogado da família recontextualizada na notícia.

$\mathrm{Na}$ reportagem, a classificação por valoração atuou de modo significativo na construção ora de uma representação positiva/favorável ao ator social, em que são ressaltadas suas qualidades, ora de uma representação desfavorável, que evidencia aspectos negativos de sua vida pessoal e profissional. E as vozes incluídas na reportagem produzem uma identificação e representação enfraquecidas do ator social, uma vez que são atreladas a sofrimento, à doença, à acusação de abuso sexual, a atitudes consideradas incomuns em nossa sociedade e destacam as fragilidades de Michael Jackson.

No editorial, a crise identitária de Michael Jackson e os dramas por ele vivenciados são enfatizados. No artigo de opinião, a valoração e a intertextualidade manifesta atuam na constituição de uma identificação e representação predominantemente positivas e fortalecidas. Na carta do leitor, ela é somente positiva e fortalecida.

Tendo em vista o poder que a mídia tem de influenciar o saber, as crenças, os valores, as relações sociais e as identidades sociais e de representar as coisas de modos particulares (FAIRCLOUGH, 1995), muitas vezes como um espetáculo, este estudo, contextualizado no debate sobre a representação em gêneros da esfera jornalística, indica o potencial de investigaçóes voltadas para o desvelamento das escolhas presentes nesses gêneros e dos diferentes sentidos potenciais por elas construídos. Indica também que a escolha das fontes e a recontextualização de seus dizeres, nos gêneros em análise, exerce papel importante na produção de diferentes representações, as quais se realizam em boa parte, especialmente nos gêneros notícia e reportagem, por meio da intertextualidade.

A análise exposta desvela a valoração como um recurso presente nos gêneros dos dois tipos de jornalismo - o informativo e o opinativo - e muito 
produtivo na construção dessas diferentes representações. Ademais, ela ilustra como os gêneros dos dois tipos de jornalismo são construídos com informações e opiniōes.

Contudo, temos clareza de que não esgotamos todas as possibilidades de análise da temática e dos gêneros. Sem dúvida, este estudo deve ser continuado em análise de mais exemplares dos gêneros selecionados e de outros gêneros e em pesquisa etnográfico-discursiva com foco na recepção dos textos.

\section{Notas}

${ }^{1}$ Este estudo corresponde a resultados parciais do projeto de pesquisa "Os gêneros da mídia impressa: a representação de fatos e de atores sociais", fomentado pela Fundação de Amparo à Pesquisa do Estado de Minas Gerais (FAPEMIG), por meio do edital 01/2010, Demanda Universal. No desenvolvimento do projeto, foram selecionados textos referentes a cinco fatos que receberam destaque na mídia de 2008 a 2011 . O estudo está subsumido a um projeto maior, intitulado "Gêneros, discursos e identidades na mídia brasileira”, coordenado pela Profa. Dra. Maria Aparecida Resende Ottoni, e vinculado ao Grupo de Pesquisas e Estudos em Análise de Discurso Crítica e Linguística Sistêmico-Funcional e ao Grupo de Pesquisa sobre Texto e Discurso, do Instituto de Letras e Linguística da Universidade Federal de Uberlândia.

${ }^{2}$ Confome Ottoni (2011, p. 198), "A recontextualização é um conceito desenvolvido na sociologia da educação (BERNSTEIN, 1996) (...) Ela diz respeito à apropriação de elementos de uma prática social dentro de uma outra, colocando a primeira dentro do contexto da última e a transformando de formas particulares no processo (BERNSTEIN, op. cit.; CHOULIARAKI \& FAIRCLOUGH, 1999)".

${ }^{3} \mathrm{Na}$ área da comunicação social, há uma divisão dos textos jornalísticos em categorias do jornalismo, em gêneros e em formatos. As categorias dizem respeito aos tipos de jornalismo como: jornalismo opinativo, jornalismo informativo, jornalismo interpretativo. Os gêneros correspondem igualmente a informativos, opinativos, interpretativos, etc. Já os formatos correspondem ao que nós, da área da Linguística, designamos como gêneros: notícia, reportagem, artigo de opinião, etc. Marques de Melo (1985) analisou vários jornais e identificou duas categorias: o jornalismo informativo e o opinativo. Na categoria jornalismo informativo, estão os gêneros: nota, notícia, reportagem e entrevista; na opinativo, estão: editorial, comentário, artigo, resenha, coluna, crônica, caricatura e carta. Em trabalho posterior, (DIAS et al., 1998), Marques de Melo e outros pesquisadores identificaram, além das duas categorias mencionadas, outras três: interpretativo, diversional e utilitário. 
${ }^{4}$ As práticas sociais são definidas como "modos habituais de ação social, ligados a um espaço e tempo particulares, nos quais as pessoas aplicam recursos (material e simbólico) para agir juntas no mundo" (CHOULIARAKI, FAIRCLOUGH, 1999, p. 21).

5 "De acordo com Fairclough (2003), uma ordem de discurso é a faceta linguística/ semiótica das redes de práticas; é uma estruturação social da diferença semiótica uma ordenação social particular de relações entre diferentes formas de construir significado, isto é, diferentes discursos, gêneros e estilos. Segundo este autor, por exemplo, a ordem de discurso política, associada com o campo político como uma articulação de práticas sociais, é constituída em um tempo e lugar particulares como uma articulação de discursos (conservador, liberal, social democrático, etc), de gêneros (debate, discurso e entrevista políticos) e de estilos, incluindo diferentes estilos de liderança política. Portanto, enquanto a atividade material, as relaçôes e processos, os fenômenos mentais e o discurso são elementos das práticas sociais (Chouliaraki e Fairclough, 1999), os gêneros, discursos e estilos são elementos das ordens de discurso" (OTTONI, 2007, p. 21-22).

${ }^{6}$ Sobre a produção, distribuição e consumo dos textos selecionados, ver item 2 deste artigo.

${ }^{7}$ No final da década de 1990, Marques de Melo retomou os estudos sobre os gêneros jornalísticos que havia feito em 1983. Juntamente com um grupo de mestrandos e doutorandos da Universidade Metodista de São Paulo (UMESP), desenvolveu mais estudos sobre o tema, cujas conclusôes foram publicadas no título "Gêneros e formatos na comunicação massiva periodística: um estudo do jornal Folha de $S$. Paulo e da revista Veja" (DIAS et al., 1998), nos anais do $21^{\circ}$ Congresso Brasileiro de Ciências da Comunicação, realizado em setembro de 1998, na cidade de Recife (PE). Neste artigo, os autores apresentam uma nova proposta classificatória, composta por cinco categorias, que são autônomas, mas se hibridizam: informativo, opinativo, interpretativo, diversional e utilitário. Na nova proposta, continuam elencados os mesmos formatos - gêneros para nós - do jornalismo informativo e do opinativo apresentados em 1985.

${ }^{8}$ Sobre a distinção gênero e formato, ver Machado (2006), Seixas (2009).

${ }^{9} \mathrm{O}$ discurso direto diz respeito à citação 'exata' do que foi dito ou escrito. Nele se utiliza um verbo dicendi, com uma demarcação clara do limite entre as vozes. Por exemplo: "A certa altura a mãe, Katherine, interrompe: 'Falam que ele é gay. Michael não é gay. Isso iria contra a religião, contra Deus'” (reportagem). Já no discurso indireto não se usam as palavras exatas ditas ou escritas, mas, sim, parafraseia-se ou resume o que foi dito ou escrito. Por exemplo: "Jackson pai dizia que o filho-prodígio era feio, criticava o rosto com espinhas e ria de seu nariz 'enorme" (reportagem). 
${ }^{10}$ Richardson (2007) usa o termo "nomeação" para designar todas as escolhas disponíveis para a representação de um evento ou de um ator social e não como nome próprio ou sobrenome, conforme concebe Van Leeuwen (1997).

${ }^{11}$ Os nomes dos gêneros foram representados pela inicial: $\mathrm{N}=$ =notícia; $\mathrm{R}=$ reportagem; $\mathrm{E}=$ editorial; $\mathrm{AO}=$ artigo de opinião; $\mathrm{CL}=$ carta do leitor.

${ }^{12}$ No dia 30/06/09, o DN Artes trouxe a seguinte manchete de uma notícia "Pai de Michael Jackson excluído do testamento do filho" (http://www.dn.pt/inicio/artes/ interior.aspx?content_id=1283131\&seccao $=$ M\%FAsica). Na biografia do pai de Michael Jackson publicada na Wikipedia, consta que "Michael Jackson confessou que quando criança foi moral e fisicamente abalado pelo seu pai por conta de contínuos ensaios obrigatórios, chicotadas, pancadas, além de inúmeros xingamentos.”. (Fonte: http://pt.wikipedia.org/wiki/Joseph_Jackson). Também em notícia divulgada em 30/11/12, aparece o seguinte trecho "?Joe está com 83 anos de idade e é conhecido pelas polêmicas envolvendo sua relação com Michael Jackson.". (Fonte: http://virgula.uol.com.br/ver/noticia/musica/2012/11/30/ 314384-pai-de-michael-jackson-sofre-avc-mas-passa-bem\#0). Esses são trechos que ilustram parte do que foi divulgado sobre a relação conflituosa entre Michael Jackson e seu pai.

\section{Referências}

BAKHTIN, M. Speech genres and other late essays. Trans. V.W. McGee. Ed. C. Emerson and M. Holquist. Austin: University of Texas Press, 1986.

BAKHTIN, M. Os gêneros do discurso. In: . Estética da criação verbal. Trad. Paulo Bezerra. São Paulo: Martins Fontes, 2003. p. 261-306.

BERNSTEIN, B. A estruturação do discurso pedagógico: classe, códigos e controle. Trad. T. T. Silva e L. F. G. Pereira. Petrópolis: Vozes, 1996.

BEZERRA, M. A. Por que cartas do leitor na sala de aula? In: DIONÍSIO, A.P.; MACHADO, A. R.; BEZERRA, M. A. (Org.). Gêneros textuais e ensino. Rio de Janeiro: Lucerna, 2002.

BOURDIEU, P. Sobre a televisão. Rio de Janeiro: Jorge Zahar Editor, 1997.

CHOULIARAKI, L.; FAIRCLOUGH, N. Discourse in late modernity: rethinking critical discourse analysis. Edinburgo: Edinburgh University Press, 1999.

COSTA, L. Teoria e Prática dos Gêneros Jornalísticos: um estudo empírico dos principais diários das cinco macro-regiōes brasileiras. 2008. Disponível em: $<$ ibict.metodista.br/tedesimplificado/tde_busca/arquivo.php?codArquivo=1925>. 
DEBORD, G. A sociedade do espetáculo. São Paulo: Ed. Paulus, 2003.

DIAS, P. da R., et al. Gêneros e formatos na comunicação massiva periodística: um estudo do jornal Folha de S. Paulo e da revista Veja. In: XXI CONGRESSO BRASILEIRO DE CIÊNCIAS DA COMUNICAÇÃO, 21, Recife, 1998. Anais... Recife, PE: Intercom, 1998, p. 1-23.

FAIRCLOUGH, N. Media Discourse. Londres: Edward Arnold, 1995.

FAIRCLOUGH, N. Discurso e mudança social. Coord. trad., revisão e pref. à ed. bras. de Izabel Magalhães. Brasília: Editora Universidade de Brasília, 2001a.

FAIRCLOUGH, N. The dialectics of discourse. Textus, v. 14, n. 2, p. 1-10, 2001 b. FAIRCLOUGH, N. Analysing discourse: textual analysis for social research. Londres e Nova York: Routledge, 2003.

FAIRCLOUGH, N. Language and globalization. Londres e Nova York: Routledge, 2006.

FAIRCLOUGH, N.; WODAK, R. Critical Discourse Analysis. In: VAN DIJK, T. (Ed.). Discourse as social interaction. Londres: Sage, 1997. p. 258-84.

FOWLER, R. Language in the news: discourse and ideology in the press. Great Britain: Routledge, 1991.

GOLDENBERG, M. A arte de pesquisar - Como fazer pesquisa qualitativa em Ciências Sociais. 5. ed. Rio de Janeiro: Record, 2001.

KRISTEVA, J. Introdução à semanálise. São Paulo: Perspectiva, 1974.

MACHADO, I. Gêneros e /ou Formatos? Design de linguagem mediada. XXIX CONGRESSO BRASILEIRO DE CIÊNCIAS DA COMUNICAÇÃO. 2006, Brasília. Anais.... São Paulo: Intercom, 2006. CD-ROM.

MARQUES DE MELO, J. (Org.). A opiniāo no jornalismo brasileiro. Petrópolis: Vozes, 1985.

MARQUES DE MELO, J. Jornalismo Opinativo: gêneros opinativos no jornalismo brasileiro. 3. ed. Campos do Jordão: Mantiqueira, 2003.

MARTINS, S. Uma lenda envolta em mistério, dentro de um enigma. Veja, ed. 2119, ano 42, n. 26, p. 96-110, 1 jul. 2009.

MAUTNER, G. Analysing newspapers, magazines and other print media. In: WODAK, R.; KRZYZANOWSKI, M. (Ed). Qualitative discourse analysis in the social sciences. New York: Palgrave Macmillan, 2008. p. 30-53.

MOTTA, L. G. (Org.). Imprensa e poder. Brasília: Editora Universidade de Brasília, 2002. 
NASCIMENTO, K. C. de S. Mecanismos argumentativos no jornalismo escrito. In: PAULIUKONIS, M. A. L.; GAVAZZI, S. (Org.). Texto e discurso: mídia, literatura e ensino. Rio de Janeiro: Lucerna, 2003. p. 85-96.

OTTONI, M.A.R. A recontextualização, a multimodalidade e o hibridismo na abordagem dos gêneros do humor. Revista do SELL. Uberaba, v. 3, n. 3, p. 196-208, 2011. Disponível em: <http://www.uftm.edu.br/revistaeletronica/index.php/sell/ article/view/183/210>. ISSN: 1983-3873

OTTONI, M.A.R. Os gêneros do humor no ensino de Lingua Portuguesa: uma abordagem discursiva crítica. 2007. 400 f. Tese (Doutorado em Linguística) Departamento de Linguística, Português e Línguas Clássicas, Universidade de Brasília, Brasília, 2007.

PENA, F. Teoria do Jornalismo. 2. ed. São Paulo: Contexto, 2006.

RAMONET, Ignacio. A tirania da comunicação. Trad. Lúcia M. E. Orth.Petrópolis: Vozes, 1999.

REISIGL, M.; WODAK, R. Discourse and discrimination: rhetorics of racismo and anti-semitism. Londres: Routledge, 2001.

RESENDE, V. de M.; RAMALHO, V. Análise de discurso crítica. São Paulo: Contexto, 2006.

RICHARDSON, J. E. Analysing newspapers: an approach from critical discourse analysis. Nova York: Palgrave Macmillan, 2007.

SEIXAS, L. Redefinindo os gêneros jornalísticos - Proposta de novos critérios de classificação. (Livro on line). LabCom, 2009.

VAN LEEUWEN, T. A representação dos atores sociais. In: PEDRO, E. R. (Org.). Análise crítica do discurso: uma perspectiva sociopolítica e funcional. Lisboa: Caminho, 1997, p. 169-222.

WODAK, R.; MEYER, M. Methods of critical discourse analysis. Londres: Sage, 2001. 